\title{
Column
}

\section{Meten is niet altijd weten}

Sytse Douma

Stel dat $u$ de leider bent van een organisatie. $U$ hebt tenminste één ondergeschikte. $U$ wilt bepaalde doelstellingen bereiken. Uw ondergeschikten moeten daaraan meewerken. Nu vraagt u zich af in hoeverre het zinvol is om de prestaties van uw ondergeschikten op de een of andere manier te meten. Met meten bedoel ik hier het op de een of andere manier in een kwantitatieve maatstaf uitdrukken van die prestaties. Draagt het meten van de prestaties van uw ondergeschikten bij aan het realiseren van uw doelstellingen? Of kunt $u$ dat meten net zo goed of zelfs beter achterwege laten? Dat is het probleem dat ik in deze column aan de orde wil stellen.

$U$ hebt in deze probleemstelling natuurlijk allang iets van het agency-probleem herkend. Nu wordt deze column zeker niet een theoretische uiteenzetting van de agency-theorie. $U$ kunt dus gerust verder lezen, het wordt niet technisch, niet moeilijk en hopelijk ook niet saai. Toch begin ik met een hele korte uiteenzetting van het agency-probleem.

Bij het standaard agency-probleem zijn er twee personen. De ene persoon noemen we de principaal. Dat bent u dus, als leider van een organisatie. De andere persoon is de agent. Dat is uw ondergeschikte. Stel dat $u$ als principaal eigenaar bent van een stuk landbouwgrond. De agent wil op deze grond aardbeien gaan verbouwen. In het standaard agency-probleem gaat men er nu van uit dat de marktwaarde van de verbouwde aardbeien (dat noemen we de output) afhankelijk is van twee factoren: van het weer en van de mate waarin de agent zich heeft ingespannen. Bovendien gaat men ervan uit dat $u$ als principaal noch het inspanningsniveau van de agent noch de weersomstandigheden kunt waarnemen. $U$ kunt echter wel vaststellen wat de marktwaarde van de verbouwde aardbeien is. Het meten van de output (de marktwaarde van de aardbeien) is dus geen probleem. De centrale vraag van de agencytheorie is nu welke beloningsstructuur $u$ als principaal aan uw agent moet aanbieden. Moet deze beloningsstructuur mede zijn gebaseerd op de gerealiseerde output? Het antwoord is in de meeste gevallen ja. Voor nadere precisering van dit antwoord verwijs ik u graag naar een andere publikatie.'

Nu terug naar uw probleem als leidinggevende van een organisatie. Stel dat $u$ president-directeur bent van een concern met een groot aantal dochterondernemingen. Uw directe ondergeschikten zijn de directeuren van die dochterondernemingen. Uw belangrijkste doelstelling is de continuiteit van het concern. Is het nu zinvol om de prestaties van uw ondergeschikten te meten? En welke maatstaf moet daarvoor dan worden gebruikt? U zult waarschijnlijk tenminste de financiële prestaties van de dochterondernemingen willen meten. Een structureel verliesgevende dochteronderneming draagt immers in het algemeen niet bij aan de continuïteit van het concern. $U$ moet wel voorzichtig zijn met het trekken van conclusies inzake de prestaties van de directeuren van de werkmaatschappijen. Een lage rentabiliteit van een bepaalde dochteronderneming hoeft niet per se het gevolg te zijn van slecht management door de directeur van die werkmaatschappij. Ook een verslechtering van de rentabiliteit in de loop van de tijd hoeft nog niet het gevolg te zijn van falend management. Omgekeerd behoeven goede financiële resultaten niet het gevolg te zijn van goed management. Te veel nadruk op de rentabiliteit van de dochteronderneming kan ertoe leiden dat niet te activeren maar voor de continuiteit op lange termijn wezenlijke uitgaven

Prof. Dr. S.W. Douma is hoogleraar in de Bedrijfseconomie, in het bijzonder de Organisatie van de Onderneming, aan de Katholieke Universiteit Brabant. 
(zoals uitgaven ten behoeve van research) worden vermeden. Te veel nadruk op de rentabiliteit van de dochteronderneming kan er ook toe leiden dat de samenwerking tussen de directeuren van verschillende werkmaatschappijen onder druk komt te staan. ${ }^{2} U$ moet dus als leider niet alleen naar de rentabiliteit kijken maar ook naar andere dingen, zoals de innovatiegraad en de bereidheid tot samenwerking. Dat zijn zaken die zich moeilijk laten vangen in een kwantitatieve maatstaf. Als aanvulling op de kwantitatieve maatstaven met betrekking tot financiële prestaties zijn die zaken echter onmisbaar.

Stel nu eens dat $u$ een leidinggevende functie hebt op het ministerie van Justitie. Uw taak is het beoordelen van de prestaties van de officieren van justitie. ${ }^{3}$ Uw doel is het voorkomen van misdaden. In hoeverre is het zinvol om de prestaties van de officieren van justitie uit te drukken in een kwantitatieve maatstaf? Welke maatstaf zou u daarvoor kunnen kiezen? Ik zal twee mogelijkheden de revue laten passeren. Stel dat u gaat meten welk percentage van de voor de rechter gebrachte gevallen door de officier wordt gewonnen. Als u daarop de prestaties van de officieren van justitie gaat beoordelen, kan dat ertoe leiden dat alleen die gevallen voor de rechter worden gebracht waarbij de officier tevoren erg zeker is van zijn zaak. Het gevolg zal zijn dat er veel zaken zullen worden geseponeerd. Potentiële misdadigers zullen dat op den duur door krijgen. Het aantal misdaden zal daardoor toenemen. $U$ bereikt op deze manier dus uw doel niet. Stel dat u kiest voor het aantal gewonnen zaken en niet voor het percentage van het totale aantal zaken dat door de officier wordt gewonnen. Als een bepaalde officier van justitie veel moordzaken wint, zal het aantal moorden in zijn district hopelijk afnemen. Daardoor zal de succesvolle officier in de toekomst minder moordzaken kunnen winnen. De officier heeft er dus geen belang bij om alle moordzaken te winnen: hij moet ook potentiële moordenaars een beetje blijven stimuleren. Doet hij dat niet dan heeft hij in de toekomst geen enkele moordzaak meer en behaalt hij dus een zeer lage score. Als u deze maatstaf kiest zal een succesvolle officier van justitie aan zijn eigen succes ten onder gaan. Een ander probleem is dat alle zaken die één officier behandelt waarschijnlijk niet even ernstig en even ingewikkeld zijn. Het winnen van een ernstige zaak (een moord bijvoorbeeld) of een erg ingewikkelde zaak (een ingenieuze fraudezaak bijvoorbeeld) moet duidelijk zwaarder tellen dan het winnen van een zaak tegen een fietsendief. Dat is een wegingsprobleem. Het vinden van één goede maatstaf is erg moeilijk, omdat het vaststellen van wegingsfactoren voor de ernst van misdrijven een moeilijke zaak is.

Dit wegingsprobleem heeft ook een grote rol gespeeld in de voormalige Sovjet-Unie. Daar heeft men geprobeerd de prestaties van fabrieken te meten in fysieke eenheden. Een schoenenfabriek moest bijvoorbeeld gedurende een bepaalde periode een bepaald aantal paren schoenen produceren. Het probleem daarbij is dat er nauwelijks enige aandacht is voor de wensen van de consument. Het is waarschijnlijk gemakkelijker om slechts een beperkt aantal maten, kleuren en modellen te produceren dan een breed assortiment. Daarom is het niet voldoende om alleen het totale aantal paren geproduceerde schoenen te meten. Zou men dat wel doen dan worden er op den duur nog uits/uitend zwarte schoenen maat veertig gemaakt. Een specificatie naar maten, modellen en kleuren is echter nog niet voldoende. Ook de kwaliteit van de schoenen moet een rol spelen. Dat leidt weer tot een wegingsprobleem. Het is misschien niet onmogelijk om dat op te lossen, maar de praktijk van de centraal geleide economieën, waarin financiële prestaties van ondernemingen minder belangrijk waren, leert toch wel dat zo'n systeem tot niet al te beste resultaten leidt. Door de financiële prestaties van de onderneming te meten worden die problemen grotendeels ondervangen. Uitsluitend meten in financiële termen is gevaarlijk, maar uitsluitend meten in fysieke eenheden is nog veel gevaarlijker.

Stel nu eens dat $u$ lid bent van het bestuur van een faculteit. Uw doelstelling is het met gegeven financiële middelen bereiken van een zo groot mogelijke kwaliteit van onderwijs en onderzoek. 


\section{MAB}

$U$ vraagt zich af of het zinvol is om de prestaties van vakgroepen of van individuele hoogleraren of universitaire docenten te meten. Nu doen zich twee problemen voor.

Het eerste probleem is dat als een persoon of een groep van personen (zoals een vakgroep) twee taken heeft (onderwijs en onderzoek), beide taken gemeten moeten worden en in de perceptie van de betrokkenen ook op gelijke wijze beloond moeten worden. Een zweetdruppeltje meer besteed aan het verhogen van de kwaliteit van het onderwijs moet dus evenveel bijdragen aan je kansen op promotie op de universitaire carrièreladder als een zweetdruppeltje extra besteed aan onderzoek. Dat is de essentie van het 'equal compensation principle'. ${ }^{4}$ Als je alleen onderzoeksprestaties meet en de beloning van universitaire medewerkers in hoofdzaak daarop baseert, dan is een onvermijdelijk gevolg dat de $k$ waliteit van het onderwijs achteruit gaat. Toch is dat precies wat aan de meeste Nederlandse faculteiten gebeurt.

Het tweede probleem heeft betrekking op de vraag wat je precies moet meten en hoe je dat moet meten. Dat is het probleem dat zich altijd voordoet als de output niet op een markt wordt verkocht en je dus geen financiële resultaten kunt berekenen. Het ministerie van Onderwijs meet de onderzoeksoutput onder andere door het aantal promoties te tellen. Per afgeleverde doctor ontvangt de betrokken universiteit een bepaald bedrag. Ik vrees dat dat op den duur zal leiden tot proefschriften met een geringere kwaliteit. Daarnaast meet het ministerie de kwaliteit van het onderwijs in termen van het onderwijsrendement. Tot voor kort was de financiering van het onderwijs uits/uitend gekoppeld aan de instroom van eerstejaars studenten, maar nu speelt ook het aantal uitgereikte doctoraalbullen een rol. Voor iedere uitgereikte doctoraalbul ontvangt de universiteit dus een bepaald bedrag. Het lijkt mij zeer waarschijnlijk dat dat op den duur zal leiden tot verlagen van de normen. De tentamenvragen zullen gemakkelijker worden en er zullen meer bullen worden uitgereikt. De kwaliteit van het onderwijs zal achteruit gaan in plaats van vooruit.

Aan economische faculteiten worden de onderzoeksprestaties van vakgroepen en individuen gemeten door het aantal publikaties per persoon te tellen en te wegen. Daarbij worden alle tijdschriften ingedeeld in categorieën: er zijn A-, B-, C-, $D$ - en $E$ bladen. Uiteraard leidt dat onvermijdelijk tot onenigheid tussen de vakgroepen over de juistheid van die indeling en over de wegingsfactoren. Is een publikatie in een A-blad tweemaal of tienmaal zo 'goed' als een publikatie in een C-blad? Omdat iedere objectieve norm ontbreekt blijven verschillen van inzicht over deze vragen bestaan. Of onderzoeksprestaties aan alle economische faculteiten met dezelfde ijver worden gemeten, weet ik niet. Ik vind het wel opvallend dat de economische faculteiten in Nederland zo weinig aandacht besteden aan belangrijke maatschappelijke vraagstukken. Zou dat wellicht samenhangen met het feit dat een publikatie over dat type onderzoek in de A-bladen (zoals de American Economic Review) heel weinig kans maakt? Een blad als ESB is slechts een D-blad, waardoor een publikatie in ESB bijna niet meetelt bij iemands wetenschappelijke produktie.

Tot slot nog even terug naar ons agency-probleem. Bij het standaard agency-probleem gaat men ervan uit dat het meten van de output geen probleem vormt. In deze column staat nu juist centraal de vraag in hoeverre het zinvol is om te proberen de output te meten. Als de output van een persoon of van een organisatie op de markt wordt verkocht is het meestal mogelijk de output te meten in financiële termen. Dat is uiterst zinvol, al moet men natuurlijk voorzichtig zijn met het trekken van conclusies. Subjectieve oordelen zijn bijna altijd nodig als aanvulling op de cijfers met betrekking tot de financiële prestaties. Als de output niet op de markt wordt verkocht is er altijd een wegingsprobleem. Je meet gauw de verkeerde dingen, waardoor je het tegenovergestelde bereikt van wat je eigenlijk wil bereiken. Meten is niet altijd weten. 


\section{MAB}

\section{Noten}

1 Sytse Douma en Hein Schreuder, Economic Approaches to Organizations, Prentice Hall, Hemel Hampstead, 1991. In het bijzonder paragraaf 6.6 .

2 Zie ook S.W. Douma, Concernhoofdkantoor en business units, Maandblad voor Accountancy en Bedriffseconomie, 65 e jaargang, nr. 6 (juni 1991), pp. 267-270.
3 Dit voorbeeld is ontleend aan Gordon Tullock, Economic Hierarchies, Organization and the Structure of Production, Kluwer Academic Publishers, Boston, 1992. Het voorbeeld wordt besproken op pp. 126/127.

4 Paul Milgrom en John Roberts, Economics, Organization and Management, Prentice Hall, Englewood Cliffs, New Jersey, 1992. Het equal compensation principle wordt behandeld in hoofdstuk 7, p. 228.

\section{VAN DE REDACTIE}

In dit nummer is de eerste aflevering van de nieuwe rubriek 'Juridische Actualiteiten' opgenomen. Deze rubriek belicht ontwikkelingen in regelgeving en jurisprudentie over diverse onderwerpen die voor accountants en bedrijfseconomen van belang zijn, met name op het terrein van het vermogensrecht, het ondernemingsrecht (met uitzondering van het jaarrekeningenrecht) en het sociaal-economisch recht. Niet alle onderwerpen komen altijd aan bod; per aflevering wordt een selectie gemaakt. Er verschijnen twee afleveringen per jaar (mei en november).

De rubriek heeft een signalerende en informerende functie.

De bijdragen zijn daarom kort en bondig en bieden geen ruimte voor uitgebreide wetenschappelijke beschouwingen. De bijdragen zijn afkomstig van verschillende auteurs. De rubriek staat onder redactie van $\mathrm{Mr}$. M. Verhorst (lid redactieraad MAB voor het ondernemingsrecht) en Prof. Mr. A.F.M. Dorresteijn (hoogleraar privaatrecht Open universiteit). 